\title{
The Effect of Some Herbal Juice Formula on Serum Total Cholesterol Level of High Lipid Diet-PTU Rats
}

\author{
$1^{\text {st }}$ Sari Meisyayati \\ STIFI Bhakti Pertiwi \\ Palembang,Indonesia \\ sari.meisyayati@gmail.com
}

\author{
$2^{\text {nd }}$ Melinda Risa \\ STIFI Bhakti Pertiwi \\ Palembang,Indonesia \\ melindarisa@gmail.com \\ $6^{\text {th }}$ Rini Isomarina $S T I F I$ \\ Bhakti Pertiwi \\ Palembang, Indonesia \\ riniisomarina@gmail.com
}

\author{
$3^{\text {rd }}$ Hera Juniati \\ STIFI Bhakti Pertiwi \\ Palembang, Indonesia \\ herajuniati@gmail.com
}

\author{
$4^{\text {th }}$ Juli Herpi STIFI \\ Bhakti Pertiwi \\ Palembang, Indonesia \\ juliherpi@gmail.com
}

Corresponding author: sari.meisyayati@gmail.com

\begin{abstract}
A significant increase in cardiovascular disease prevalence among the Indonesian according to Riskesdas in 2018. Therefore an alternative treatment with minimum side effects to decrease serum total cholesterol is required. Some herbal with anti-hyperlipidemic activity and has a great safety profile can be combined as a mixture to achieve high pharmacology activity with a better taste. Three types of herbal formulas were made from the combination of the juice of garlic, roselle calyx, red ginger, citrus lemon, pineapple, apple cider vinegar, and honey. The variations of the formula were based on the addition of roselle, and pineapple to the composition of garlic, red ginger, citrus lemon, apple cider vinegar, and honey. The doses used in each formula were 2.7 $\mathrm{ml} / \mathrm{kg} \mathrm{BW}$ and $5.4 \mathrm{ml} / \mathrm{kg} \mathrm{BW}$. Each formula was given once a day for $10^{\text {th }}$ day along with high lipid diet-PTU to the animals. Total cholesterol levels were measured digitally through tail vein one day before and after treatment. All herbal juice formula significantly decreased of total cholesterol level of the high lipid dietPTU rat and it's linear with the dose. The addition of roselle calyx and pineapple each on the herbal juice formula will raise the anti-hyperlipidemic effect. The herbal juice contained roselle showed the highest antihyperlidemic effect at the dose of $5.4 \mathrm{ml} / \mathrm{kg} \mathrm{BW}$.

Keywords: Roselle, pineapple, garlic, red ginger,citrus lemon, apple cider vinegar,anti-hyperlipidemic, herbal juice.
\end{abstract}

\section{INTRODUCTION}

The relation between serum total cholesterol level and coronary heart disease is well established. Moreover, according to the JACC Study, high levels of serum total cholesterol levels were associated with high mortality from coronary heart disease among Japanese [1]. Another study on the Korean population also revealed the association between elevated risk for allcause mortality and an increased or persistent high cholesterol levels [2]. Indonesia Basic Health Research (Riskesdas) in 2018 has reported a significant increase in cardiovascular disease prevalence among Indonesian from Riskesdas in 2013. There are $7.6 \%$ of the Indonesian population have high cholesterol levels and $21.2 \%$ of Indonesian people at borderline levels [3]. Several factors contribute to this condition including age, obesity, lifestyle, and smoking [4]. Therefore, control of serum cholesterol levels is needed mostly for cardiovascular disease patients.

Lowering high cholesterol can be treated by diet and changing behavior. Some medications by using lipidlowering agents also can be used concomitantly if the diet failed such as statins, fibrates, niacin, and bile acid resins. Statins are the most effective agent to lower LDL-C but it also has an adverse effect [5]. Myopathy is a common adverse effect with myalgia and fatigue as symptoms. Hence, alternative treatment with minimum side effects to decrease serum total cholesterol is required. There is a lot of complimentary herbals that have been tested scientifically for anti-hyperlipidemic activity and also has a great safety profile There are garlic, roselle, red ginger, citrus lemon, pineapple and apple cider vinegar that already known to have antihyperlipidemic activity based on some research. 
Garlic can inhibit human squalanemonooxidase and HMG-CoA reductase, enzymes involved in cholesterol biosynthesis [6]. Roselle calyces can decrease triglycerides serum of metabolic syndrome patients [7]. The study of red ginger rhizomes ethanol extract on hyperlipidemia induced rats also shown significant enhancing lipid profiles [8]. Citrus lemon juice can reduce serum total cholesterol in rabbits after four weeks of consumptions [9]. Pineapple juice showed decreased total cholesterol and LDL- cholesterol on Wistar rats. It also has an anti-obesity effect [10]. Apple cider vinegar intake for more than eight weeks also showed the same effect on hyperlipidemic patients in Iran [11]. The fact that they can be used as single to enhance blood lipid profile has limitations according to high dose and lack of acceptance taste such bitter or sour. Thus, the combination of those herbal is expected to have synergetic anti-hyperlipidemia from each component eventually will reduce the dose. Furthermore, modifying these herbal to some formula of herbal juice can achieve high pharmacology activity with a better taste.

\section{RESEARCH METHODOLOGY}

\section{A. Materials}

The materials used in this study were garlic, roselle calyx, red ginger, citrus lemon, pineapple, apple cider vinegar, and honey. Simvastatin, high lipid diet (HLD), propylthiouracil (PTU), male Wistar rat, cholesterol digital meter.

Tabel 1. Herbal Juice Formula Herbal Juice Compositions

\begin{tabular}{|c|c|c|c|c|c|}
\hline \multirow{2}{*}{\multicolumn{2}{|c|}{ Formula I }} & \multicolumn{2}{|c|}{ Formula II } & \multicolumn{2}{|c|}{ Formula III } \\
\hline & & RJ & $20 \mathrm{ml}$ & PJ & $30 \mathrm{ml}$ \\
\hline GJ & $10 \mathrm{ml}$ & GJ & $10 \mathrm{ml}$ & GJ & $10 \mathrm{ml}$ \\
\hline RGRJ & $30 \mathrm{ml}$ & RGRJ & $30 \mathrm{ml}$ & RGRJ & $30 \mathrm{ml}$ \\
\hline CLJ & $10 \mathrm{ml}$ & CLJ & $10 \mathrm{ml}$ & CLJ & $10 \mathrm{ml}$ \\
\hline $\mathrm{ACV}$ & $10 \mathrm{ml}$ & $\mathrm{ACV}$ & $10 \mathrm{ml}$ & $\mathrm{ACV}$ & $10 \mathrm{ml}$ \\
\hline \multicolumn{2}{|c|}{$\begin{array}{l}\text { Honey ad until } 150 \\
\mathrm{ml}\end{array}$} & Honey & $\begin{array}{c}\text { ad until } 150 \\
\mathrm{ml}\end{array}$ & \multicolumn{2}{|c|}{$\begin{array}{l}\text { Honey ad until } 150 \\
\mathrm{ml}\end{array}$} \\
\hline \multicolumn{6}{|c|}{$\begin{array}{l}\text { GJ: garlic juice, RGRJ: red ginger rhizome juice, CLJ: } \\
\text { citrus lemon juice,ACV: apple cider vinegar, RJ: roselle } \\
\text { juice, and PJ: pineapple juice }\end{array}$} \\
\hline
\end{tabular}

\section{B. Methods}

\section{Formulation of herbal juice}

Three types of herbal formulas were made from the combination of the juice of garlic, roselle calyx, red ginger, citrus lemon, pineapple, apple cider vinegar, and honey. The Formula I consisted of the juice of garlic, red ginger, citrus lemon, apple cider, and honey. Formula II consisted of the juice of pineapple, garlic, red ginger, citrus lemon, apple cider vinegar, and honey. Formula III consisted of the juice of roselle calyx, garlic, red ginger, citrus lemon, apple cider, and honey. Each formula was made by mixing each of the juice then warmed the mixture in the glass bowl until shimmering. Apple cider vinegar and honey were added to the mixture when it achieved room temperature.

\section{Anti-hyperlipidemic test}

45 Male Wistar rats were divided into 9 groups after 1-week acclimatization. Each group contained five animals. Group I, was animals without high lipid dietPTU intake. Group II, was animals with high lipid diet-PTU intake and only given $0.5 \%$ w/v of NaCMC suspensions orally. Group III, was animals with high lipid diet-PTU intake and given $0.9 \mathrm{mg} / \mathrm{kg} \mathrm{BW}$ of simvastatin. Group IV, V, VI, VIII, and IX were animals with high lipid diet-PTU intake and given each herbal juice formula at a dose of $2.7 \mathrm{ml} / \mathrm{kg} \mathrm{BW}$ (low dose) and $5.4 \mathrm{ml} / \mathrm{kg} \quad \mathrm{BW}$ (high dose) respectively. $0.1 \%$ of PTU was given as drinking water to the animal. Each test substance was given once a day for 10th days including HFD-PTU except group I. Serum total cholesterol levels were measured by digitally 1 day before and after treatment.

\section{Data Analysis}

All the values were expressed as the mean and standard error to the mean. Shapiro Wilk and Levene's Test were used to see normality and homogeneity of the data. ANOVA one way was performed to see mean difference among group, $\mathrm{P}$ Values $<0.05 \mathrm{ere}$ considered as significant.

\section{RESULTS}

Tabel 2. Total Cholesterol Levels Among the Group of Animals

\begin{tabular}{lllc}
\hline \multicolumn{1}{c}{$\begin{array}{c}\text { Group of } \\
\text { Animals }\end{array}$} & \multicolumn{2}{c}{ Blood Total Cholesterol (mg/d) } & \multirow{2}{*}{$\begin{array}{c}\text { Decrement } \\
(\boldsymbol{\%})\end{array}$} \\
\cline { 2 - 3 } $\begin{array}{l}\text { Non-HLD-PTU } \\
\text { Control }\end{array}$ & $172,2 \pm 14,720$ & $188,8 \pm 15,287$ & $-9,62 \pm 0,97^{*}$ \\
\hline $\begin{array}{l}\text { HLD-PTU } \\
\text { Control }\end{array}$ & $180,6 \pm 9,154$ & $247,8 \pm 13,989$ & $-37,12 \pm 1,27$ \\
\hline $\begin{array}{l}\text { HLD-PTU } \\
\text { Simvastatin }\end{array}$ & $167,8 \pm 18,267$ & $135,8 \pm 13,535$ & $18,98 \pm 0,95^{*}$ \\
\hline $\begin{array}{l}\text { HLD-PTU +HJ I } \\
\text { low dose }\end{array}$ & $161,2 \pm 11,432$ & $136 \pm 8,717$ & $15,56 \pm 1,31^{*}$ \\
\hline $\begin{array}{l}\text { HLD-PTU +HJ I } \\
\text { high dose }\end{array}$ & $168 \pm 19,403$ & $135,2 \pm 14,720$ & $19,42 \pm 1,112^{*}$ \\
\hline $\begin{array}{l}\text { HLD-PTU +HJ II } \\
\text { low dose }\end{array}$ & $176,4 \pm 15,915$ & $143,2 \pm 13,935$ & $18,8 \pm 1,226^{*}$ \\
\hline $\begin{array}{l}\text { HLD-PTU +HJ II } \\
\text { high dose }\end{array}$ & $176,4 \pm 15,662$ & $136,4 \pm 11,588$ & $22,6 \pm 1,12^{*}$ \\
\hline $\begin{array}{l}\text { HLD-PTU +HJ } \\
\text { III low dose }\end{array}$ & $164,8 \pm 24,3$ & $135,2 \pm 19,9$ & $18,62 \pm 1,27^{*}$ \\
\hline $\begin{array}{l}\text { HLD-PTU +HJ } \\
\text { III high dose }\end{array}$ & $162,2 \pm 24,2$ & $129 \pm 19,9$ & $21,11 \pm 4,52^{*}$ \\
\hline
\end{tabular}


Values are expressed as mean \pm Standar deviation of 5 rats. HJ I: Herbal Juice Formula I, HJ II: Herbal Juice Formula II (addition of pineapple), HJ III (addition of roselle): low dose:

$2.7 \mathrm{ml} / \mathrm{kg} \mathrm{BW}$, high dose: $5.4 \mathrm{ml} / \mathrm{kg} \mathrm{BW.*}$ : significant $(\mathrm{P}<0.05)$ compared to high lipid diet-PTU rats.

Figure 1. Histogram of Total Cholesterol Decrement of All Group After $10^{\text {th }}$ day Treatment

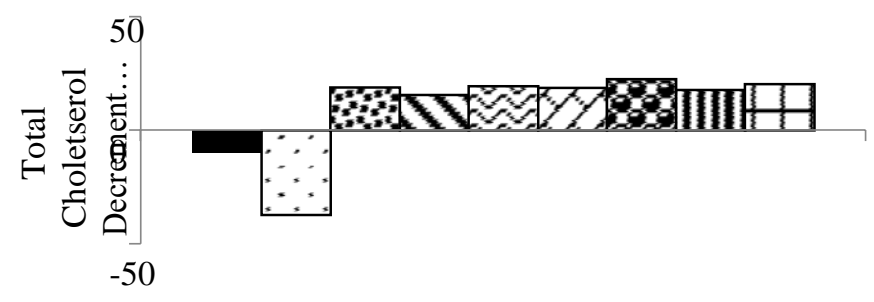

\section{D I S C U S S I O N}

A lot of complimentary and medicinal herbs were already observed scientifically for some pharmacology activities and anti-hyperlipidemic effect was one of it. Garlic, red ginger, citrus lemon, apple cider vinegar, roselle and pineapple has shown the effect. Therefore, it can be used to hyperlipidemia treatment to help maintain blood lipid levels clinically. Unfortunately, the benefit of this herb is limited by unpleasant taste, smell and the dose if using alone. It needs high dose to perform anti-hyperlipidemic effect. Combining these herbs into some formula mixture and evaluating the anti-hyperlipidemic effect can be an alternative solution to the problem.

The three herbal juice used in this study was an improved formula that has been selected by volunteers from the taste. Formula I was a herbal juice that compositions has already known empirically. Formula II and III were modifications of formula I by adding another herbal which were roselle and pineapple respectively. The two additional herbals were chosen based on their anti-hyperlipidemic activity. The dose of the

herbal juice was converted to rats from the previous clinical study of formula I [12], [13].

Both non-high lipid diet-PTU and high lipid diet-PTU rats showed a significant elevation in total cholesterol levels (Table 2, Figure 1). The highest incline was on the high lipid diet-PTU rats. The total cholesterol levels of this group reached $247.8 \mathrm{mg} / \mathrm{dL}$ which could be categorized as hyperlipidemia conditions (> 200 $\mathrm{mg} / \mathrm{dL})$. The inclination caused by the saturated fat and quail egg in the high lipid diet and propylthiouracil which inhibit thyroid peroxidase [14]. As result of less thyroid hormone caused by PTU, decrease low-density lipoprotein receptor activity. and diminish control of triiodothyronine which modulates cholesterol biosynthesis [15]. The non-high lipid diets-PTU rats also showed an incline at $10^{\text {th }}$ day treatment but the total cholesterol levels still in normal range $(<200$ $\mathrm{mg} / \mathrm{dl})$. The inclination caused by standard diets which also have fats conten.

After 10 days administration of each herbal juice formula at the dose of $2.7 \mathrm{ml} / \mathrm{kg} \mathrm{BW}$ and $5.4 \mathrm{ml} / \mathrm{kg}$, BW to rats fed with high lipid diets-PTU water intake caused a significant decline in total cholesterol levels in blood compared to non-high lipid diet-PTU rats and high lipid diet-PTU rats. It was also shown the decrement of total cholesterol level raised at the high dose.

(Table 2, Figure 2). From the three types of herbal juice formula, the addition of rosella consistently elevating the anti- hyperlipidemic activity both in low and high doses. Inhibition of lingual and gastric lipases by extract constituents increases intact triacylglyceride excretion preventing acetyl-CoA generation and hence triacylglyceride and cholesterol biosynthesis. Another study also showed,procathecuit acid (PCA), anthocyanins, and polyphenols, inhibited LDL oxidation [16]. This phenomenon also showed by the administration herbal juice formula with the addition of pineapple juice. The anti-hyperlipidemic effect of pineapple mechanism was from inhibition of pancreatic lipase activity and cholesterol micelle solubility [17]. It means the addition of roselle and pineapple also add the anti-hyperlipidemic activity to herbal juice. The highest effect was shown at a dose of $5.4 \mathrm{ml} / \mathrm{kg} \mathrm{BW}$ of herbal juice with roselle addition. The roselle has multiple mechanisms in decreasing blood lipids. Consequently, It caused higher antihyperlipidemic activy.

\section{CONCLUSION}

All herbal juice formula significantly can decrease serum total cholesterol levels at a dose of $2.7 \mathrm{ml} / \mathrm{kg}$ $\mathrm{BW}$ and $5.4 \mathrm{ml} / \mathrm{kg} \mathrm{BW}$. Moreover, the herbal juice formula with rosella calyx, garlic, red ginger, citrus lemon, apple cider vinegar, and honey at a dose of 5.4 $\mathrm{ml} / \mathrm{kg} \mathrm{BW}$ has the highest anti-hyperlipidemic effect.

\section{ACKNOWLEDGMENT}

The authors gratefully thank to Sekolah Tinggi Ilmu Farmasi Bhakti Pertiwi for financial support. 


\section{REFERENCES}

[1] Jeong SM, Choi S, Kim K, Kim SM, Lee G, Son JS, et al. Association of change in total cholesterol level with mortality: A population-based study. PLoS One 2018;13:1-11. https://doi.org/10.1371/journal.pone.0196030.

[2] Cui $\mathrm{R}$, Iso $\mathrm{H}$, Toyoshima $\mathrm{H}$, Date $\mathrm{C}$, Yamamoto A, Kikuchi S, et al. Serum total cholesterol levels and risk of mortality from stroke and coronary heart disease in Japanese: The JACC study. Atherosclerosis 2007; $194: 415-20$

https://doi.org/10.1016/j.atherosclerosis.2006.08.022

[3] Kementrian Kesehatan RI. Laporan Riskesdas 2018. Lap Nas RIskesdas 2018 2018;53:181-222.

[4] Dipiro J, Talbert RL, Yee GC, Matzke GR, Wells BG, Posey LM. Pharmacoterapy A Phatophysiologic Approach. 2015.

[5] Thornber CW, Shaw A. Antihypertensive Agents. vol. 12. 1977. https://doi.org/10.1016/S0065-7743(08)61545-6.

[6] Gebhardt R. Multiple inhibitory effects of garlic extracts on cholesterol biosynthesis in hepatocytes. Lipids 1993;28:613-9. https://doi.org/10.1007/BF02536055.

[7] Asgary S, Soltani R, Zolghadr M, Keshvari M, Sarrafzadegan N. Evaluation of the effects of roselle (Hibiscus sabdariffa L.) on oxidative stress and serum levels of lipids, insulin and hs-CRP in adult patients with metabolic syndrome: A double-blind placebo- controlled clinical trial. J Complement Integr Med 2016;13:175-80. https://doi.org/10.1515/jcim-2015-0030.

[8] Safitri D, Kurniati NF, Adharani S, Suciyati SW, Adnyana IK. The study of red ginger Rhizomes ethanol extract (Zingiber Officinale Roscoe Var. Sunti Val.) on hyperlipidemic-induced rats. Pharmacologyonline 2016;3:15-21.

[9] Khan Y, Khan RA, Afroz S, Siddiq A. Evaluation of Hypolipidemic effect of Citrus Lemon. J Basic Appl Sci 2010;6:39-43. El-Shazly SA, Ahmed MM, AL-Harbi MS, Alkafafy ME, El-Sawy HB, Amer SAM. Physiological and molecular study on the anti- obesity effects of pineapple (Ananas comosus) juice in male Wistar rat. Food Sci Biotechnol 2018;27:1429-38. https://doi.org/10.1007/s10068-0180378-1.

[10] Beheshti Z, Huak Chan Y, Sharif Nia H, Hajihosseini F, Nazari R, Shaabani M, et al. Influence of apple cider vinegar on blood lipids. Life Sci J 2012;9:2431-40.

[11] Meisyayati S, Apriyanto W, Rikmasari Y. Efek Imunomodulator Jus Herbal Kombinasi Bawang Putih, Jahe Merah, Jeruk Nipis, Cuka Apel Dan Madu Terhadap Mencit Putih Jantan. J Ilm Bakti Farm 2016;1:59-66.

[12] F E. Efek Penurunan Kadar Kolestrol Total Jus Herbal Kombinasi (Bawang Putih, Jahe Merah, Jeruk Nipis, Cuka Apel, dan Madu) pada Penderita Hiperkolestrol Wanita. Bhakti Pertiwi, 2015.

[13] Thomas JA, Keenan EJ. Principles of Endocrine Pharmacology. 1986. https://doi.org/10.1007/978-1-46845036-1.

[14] Chiellini G, Cioffi F, Senese R, De Lange P. Editorial: Thyroid hormone and metabolites: Central versus peripheral effects. Front Endocrinol (Lausanne) 2019;10.https://doi.org/10.3389/fendo.2019.00240.

[15] Carvajal-Zarrabal O, María D, Barradas-Dermitz, OrtaFlores Z, Margaret P, Hayward-Jones, et al. Hibiscus sabdariffa L., roselle calyx, from ethnobotany to pharmacology. J Exp Pharmacol 2012;4:25-39. https://doi.org/10.2147/JEP.S27974.
[16] Trisat K, Limpeanchob N, Ounaroon A. Guava, Papaya, Pineapple, and Pomelo juices Inhibit Pancreatic Lipase Activity and Cholesterol Micelle Solubility. Thai J Pharmacol 2016;38:5-14. 